\title{
African islands and the formation of the Dutch Atlantic economy: Arguin, Gorée, Cape Verde and São Tomé, I 590-I670
}

The International Journal of Maritime History

(C) The Author(s) 2014

Reprints and permissions: sagepub.co.uk/journalsPermissions.nav DOI: |0.I|77/084387|4|4543447 ijh.sagepub.com

\section{Filipa Ribeiro da Silva}

\begin{abstract}
The role played by Atlantic islands in the formation of European overseas empires, and the development of coastal and intercontinental commercial routes and business networks is relatively well studied for the Iberian Atlantic. Few scholars have, however, examined the functions of isles in the building of Dutch maritime connections. This paper partially fills this void in the literature by looking at the African Islands of Arguin, Gorée, Cape Verde and São Tomé, and highlighting their significance within the seventeenthcentury Dutch Atlantic. Using information from the notarial archives of Amsterdam, the collection of the Dutch West India Company (WIC) and journals of voyages, we examine the role played by these islands in the formation and operationalization of Dutch commercial circuits in the Atlantic, and emphasize their geo-strategic importance for the achievement of the colonial aspirations and military ambitions of the Dutch Republic and the WIC.
\end{abstract}

\section{Keywords}

Africa, Cape Verde, commerce, defence, islands, navigation, São Tomé

\section{Introduction}

The role of islands in the European maritime expansion into the Atlantic, Indian and Pacific Oceans has been widely recognized by scholars, particularly specialists dedicated

\section{Corresponding author:}

Filipa Ribeiro da Silva, Department of History, University of Macau, SAR China.

Email: fsilva@umac.mo 
to the study of the Iberian empires. ${ }^{1}$ Several studies have also emphasized the role played by islands in the formation and shaping of French, British and Dutch maritime enterprises. $^{2}$ Most of these studies, whether they have examined the Iberian, French or northern European empires, have focused mainly on islands in the Indian Ocean and the North Atlantic, especially on the cases of Madeira, Azores and the Canaries, as well as Caribbean islands such as Curaçao, Barbados, Guadeloupe and Martinique. ${ }^{3}$

1. On islands and the Iberian empires, see, for instance: Michael N. Pearson, Port cities and intruders: The Swahili Coast, India, and Portugal in the early modern era (Baltimore, 1998); Michael N. Pearson, Coastal Western India: Studies from the Portuguese records (New Delhi, 1981); Luís Filipe F.R. Thomaz and Manuel Joaquim Pintado, Early Portuguese Malacca (Macau, 2000); Paulo Jorge de Sousa Pinto, Portugueses e malaios: Malaca e os Sultanatos de Johor e Achém, 1575-1619 (Lisboa, 1997); Luís Filipe F.R. Thomaz, De Ceuta a Timor (Lisboa, 1994); Luís Filipe F.R. Thomaz, Nina Chatu and the Portuguese trade in Malacca (Bandar Melaka, 1991); Malyn Newitt, A History of Mozambique (London, 1995); O.J.O. Ferreira, Ilha de Moçambique byna Hollands: Nederlandse blokkade van Mosambiek-eiland in 1604, 1607 en 1608 (Jeffreysbaai, 2007). Joseph Frederick Mbwiliza, 'Towards a political economy of northern Mozambique: The hinterland of Mozambique Island 1600-1900' (unpublished $\mathrm{PhD}$ thesis, Columbia University, 1987); Charles R. Boxer, Moçambique island as a way-station for Portuguese East-Indiamen (London, 1962); Charles R. Boxer, Moçambique island and the carreira da Índia (Lisboa, 1961).

2. On islands in the Indian Ocean and their role in different empires, see, for instance: Shawkat M. Toorawa and Hassam Toorawa Trust, The Western Indian Ocean: Essays on islands and islanders (Port Louis, 2007). On Mauritius, see: Anthony J. Barker, Slavery and antislavery in Mauritius, 1810-33: The conflict between economic expansion and humanitarian reform under British rule (Basingstoke, 1996); Richard Blair Allen, 'Free women of colour and socio-economic marginality in Mauritius, 1767-1830', Slavery and Abolition, 26, No. 2 (2005), pp.181-97; Richard Blair Allen, 'Capital, Illegal Slaves, Indentured Labourers and the Creation of a Sugar Plantation Economy in Mauritius, 1810-60', The Journal of Imperial and Commonwealth History, 36, No. 2 (2008), pp.151-70; P.J. Moree, A concise history of Dutch Mauritius, 1598-1710: A fruitful and healthy land (Leiden, 1998). On Hong Kong and other Borneo, see, for example, Alain Le Pichon, China trade and empire: Jardine, Matheson \& Co. and the origins of British rule in Hong Kong, 1827-1843 (Oxford, 2006); L.R. Wright, The origins of British Borneo (Hong Kong, 1970). On Ceylon/Sri Lanka, see, for instance: Albert van den Belt, Het VOC-bedrijf op Ceylon: Een voorname vestiging van de Oost-Indische Compagnie in de 18de eeuw (Zutphen, 2008); Alicia Schrikker, Dutch and British Colonial Intervention in Sri Lanka, 1780-1815 (Leiden, 2007); Lodewijk Wagenaar, Galle, VOC-vestiging in Ceylon: Beschrijving van een koloniale samenleving aan de vooravond van de Singalese opstand tegen het Nederlandse gezag, 1760 (Amsterdam, 1994); P.E. Pieris, Ceylon, the Portuguese era: Being a history of the island for the period, 1505-1658 (Dehiwala, 1983); George D. Winius, The fatal history of Portuguese Ceylon; Transition to Dutch rule (Cambridge, 1971). On Taiwan/Formosa, see, for instance: Leonard Blussé and Natalie Everts, The Formosan encounter: Notes on Formosa's Aboriginal society: A selection of documents from Dutch archival sources, 4 vols. (Taipei, 1999-2010); John E. Wills, Eclipsed entrepots of the Western Pacific: Taiwan and Central Vietnam, 1500-1800 (Aldershot, 2002); Hsin-hui Chiu, The colonial 'civilizing process' in Dutch Formosa, 16241662 (Leiden, 2008).

3. On Madeira, see, for instance: Miguel Jasmins Rodrigues, Organização dos poderes e estructura social: A ilha da Madeira, 1460-1521 (Cascais, 1996); José Manuel Azevedo 
Little attention has been devoted, however, to the islands off the coast of western Africa, studies of the Canary, Cape Verde and São Tomé archipelagos in the context of Iberian maritime expansion and settlement being rare exceptions, as well as the studies

e Silva, A Madeira e a construção do mundo atlântico, séculos XV-XVII (Funchal, 1995); Alberto Vieira, Portugal y las islas del Atlántico (Madrid, 1992); Alberto Vieira, O comércio inter-insular: Nos séculos XV e XVI: Madeira, Açores e Canárias (alguns elementos para o seu estudo) (Funchal, 1987); T. Bentley Duncan, Atlantic Islands: Madeira, the Azores, and the Cape Verdes in seventeenth-century commerce and navigation (Chicago, 1972).

On the Azores, see, for example: Ricardo Manuel Madruga da Costa Os Açores em finais do regime de Capitanía-Geral, 1800-1820 (Horta, 2005); João Marinho dos Santos, Os Açores nos sécs. XV e XVI (Azores, 1989); Maria Isabel João, Os Açores no século XIX: economia, sociedade e movimentos autonomistas (Lisbon, 1991); Avelino de Freitas de Meneses, Os Açores e o domínio filipino, 1580-1590 (Angra do Heroísmo, 1987); Instituto Histórico da Ilha Terceira, Os Açores e o Atlântico (séculos XIV-XVII): Actas do colóquio internacional realizado em Angra do Heroísmo de 8 a 13 de agosto de 1983 (Angra do Heroísmo, 1984).

On islands under French control and influence in the Atlantic Ocean, see, for example: Dale W. Tomich, Slavery in the circuit of sugar: Martinique and the world economy, 18301848 (Baltimore, 1990); Jean-Pierre Sainton, Raymond Boutin et al, Histoire et civilisation de la Caraïbe: Guadeloupe, Martinique, petites Antilles: La construction des sociétés antillaises des origines au temps présent, structures et dynamiques (Paris, 2004); Paul Butel, Histoire des Antilles françaises: XVIIe-XXe siècle (Paris, 2002); Stewart R. King, Blue coat or powdered wig: Free people of color in pre-revolutionary Saint Domingue (Athens, 2001); Carolyn E. Fick, The making of Haiti: The Saint Domingue revolution from below (Knoxville, 1990); David Patrick Geggus, Slavery, war, and revolution: The British occupation of Saint Domingue, 1793-1798 (Oxford, 1982); Michel C. Hector and Claude D. Moise, La régime colonial français a Saint Domingue, 1625-1789 (Port-au-Prince, 1962).

On islands under English control and influence in the Atlantic Ocean, see, for instance: Pedro L.V. Welch, Slave society in the city: Bridgetown, Barbados 1680-1834 (Kingston, 2004); Hilary Beckles, A history of Barbados: From Amerindian settlement to Caribbean single market (Cambridge, 2006); Larry Dale Gragg, Englishmen transplanted: The English colonization of Barbados, 1627-1660 (Oxford, 2003); Trevor G. Burnard, British Atlantic world (Oxford, 2010).

On islands under Dutch control and influence in the Atlantic Ocean, see, for instance: Linda Marguerite Rupert, Creolization and contraband: Curaçao in the early modern Atlantic world (Athens, 2012); Ana Crespo Solana and Maria Dolores Gonzalez-Ripoll, eds., Historia de las Antillas no Hispanas (Madrid, 2011); Han Jordan, 'The Curaçao Slave market: From Asiento Trade to Free Trade, 1700-1730', in Johannes Postma and Victor Enthoven, eds., Riches from Atlantic Commerce: Dutch Transatlantic Trade and Shipping, 1585-1817 (Leiden, 2003), pp.219-57; Luc Alofs, Leo Dalhuisen et al, Geschiedenis van de Antillen: Aruba, Bonaire, Curaçao, Saba, Sint Eustatius, Sint Maarten (Zutphen, 1997); Cornelis Ch Goslinga, A short history of the Netherlands Antilles and Surinam (The Hague, 1979); Cornelis Ch Goslinga, The Dutch in the Caribbean and on the Wild Coast 1580-1680 (Gainesville, 1971); Cornelis Ch Goslinga, The Dutch in the Caribbean and in the Guianas, 1680-1791 (Assen, 1985); Cornelis Ch Goslinga, The Dutch in the Caribbean and in Surinam, 1791/5-1942 (Assen, 1990); Cornelis Ch Goslinga, Los Holandeses en el Caribe (La Habana, 1983); Cornelis Ch Goslinga, 'Curaçao as a slave-trading centre during the War of the Spanish Succession (1702-1714)', Nieuwe West-Indische gids, 52 (1977), pp.1-50. 
of Koltermann, Monod and Delcourt on the islands of Arguin and Gorée. ${ }^{4}$ In the scholarly literature dedicated to the maritime expansion of the Dutch Republic into the Atlantic, there are few references to the role of African islands, ${ }^{5}$ despite their key importance at a political, administrative, military, naval and commercial level in the initial period of Dutch commercial and military expansion. This study aims to partially to fill this gap in the literature by examining the islands of Arguin, Gorée, Cape Verde and São

4. On the Canary Islands, see, for instance: Santiago de Luxán Meléndez, Los puertos francos de Canarias: Ciento cincuenta años de historia (Las Palmas, 2004); Germán Santana Pérez and Juan Manuel Santana Pérez, La puerta afortunada: Canarias en las relaciones hispanoafricanas de los siglos XVII y XVIII (Madrid, 2002); Luis Pérez Aguado, La caña de azúcar en el desarrollo de la ciudad de Telde (siglo XVI) (Telde, 2001); María Elena Fernández Montes, Naviós y gente de mar: Siglos XVI-XVIII (Tenerife, 2000); José Manuel Castellano Gil, Francisco J. Macias Martín, Ma del Pino Minguez Espino and Manuel de Paz, History of the Canary Islands (Tenerife, 1993); Pablo Emilio Pérez-Mallaína Bueno, La metrópoli insular: Rivalidad comercial canario-sevillana, 1650-1708 (Las Palmas, 1993); Antonio de Béthencourt Massieu, Canarias e Inglaterra: El comercio de vinos, 1650-1800 (Las Palmas, 1991); Elisa Torres Santana, El comercio de las Canarias orientales en tiempos de Felipe III (Las Palmas, 1991); Manuel Lobo Cabrera, El comercio canario europeo bajo Felipe II (Funchal, 1988); Felipe Fernández-Armesto, The Canary Islands after the conquest: The making of a colonial society in the early sixteenth century (Oxford, 1982); John Mercer, The Canary Islanders: Their prehistory, conquest, and survival (London, 1980); Antonio Rumeu de Armas, Piraterías y ataques navales contra las islas Canarias (Madrid, 1947-50).

On the islands of Arguin and Gorée, see, for instance: Philip Koltermann, Zur brandenburgischen Kolonialgeschichte: die Insel Arguin vor der Küste Mauretaniens (Potsdam, 1999); Jean Delcourt (Pére), Gorée: six siècles d'histoire (s.1., 1984); Guy Thilmans, La grande batterie de Gorée: Recherches archéologiques et historiques (Gorée, 2006); Guy Thilmans, Histoire militaire de Gorée: De l'arrivée des Portugais (1444) au départ définitif des Anglais (1817), (Gorée, 2006).

5. W.S. Unger, 'Nieuwe gegevens betreffende het begin der vaart op Guinea', Economischhistorisch Jaarboek, 21 (1940), pp.194-217; Henk den Heijer, De geschiedenis van de WIC (Zutphen, 1994); Henk den Heijer, Goud, ivoor en slaven: scheepvaart en handel van de Tweede Westindische Compagnie op Afrika, 1674-1740 (Zutphen, 1997); Henk den Heijer, 'The Western African Trade of the Dutch West India Company, 1674-1740', in Johannes Postma and Victor Enthoven, eds., Riches from Atlantic Commerce: Dutch Transatlantic Trade and Shipping, 1585-1817 (Leiden, 2003), pp.139-70; Klaas Ratelband, Nederlanders in West-Afrika (1600-1650): Angola, Kongo en São Tomé (Zutphen, 2000); Os Holandeses no Brasil e na Costa Africana. Angola, Kongo e São Tomé (1600-1650) (Lisboa, 2003); Victor Enthoven, 'Early Dutch Expansion in the Atlantic Region, 1585-1621', in Johannes Postma and Victor Enthoven, eds., Riches from Atlantic Commerce: Dutch Transatlantic Trade and Shipping, 1585-1817 (Leiden, 2003), pp.17-47. Ruud Paesie, Lorrendrayen op Africa. De Illegale goederen- en slavenhandel op West-Afrika tijdens het achttiende-eeuwse handelsmonopolie van de West-Indische Compagnie, 1700-1734 (Amsterdam, 2008); Filipa Ribeiro da Silva, 'Dutch vessels in African waters: Coastal routes and intra-continental trade (c.15901674)', Tijdschrift voor Zeegeschiedenis, 1 (2010), pp.19-38; Filipa Ribeiro da Silva, 'Dutch trade with Senegambia, Guinea and Cape Verde, c.1590-1674', in Toby Green, ed., Brokers of Change: Atlantic Commerce and Cultures in Pre-colonial Western Africa (Oxford, 2012), pp.125-48. 
Tomé, and assessing their role in the activities of private merchants based in key Dutch port-cities, the State-sponsored chartered companies, the first and second Dutch West India Company (WIC, 1621-1674; 1674-1792), and the ambitions of States General of the Dutch Republic.

Our analysis of the role of islands in the Dutch Atlantic will cover three different periods: i) c.1590-1623; ii) $1624-1640 \mathrm{~s}$ and iii) $1640 \mathrm{~s}-1670 \mathrm{~s}$. These chronological boundaries correspond to three major periods in the process of Dutch expansion in the Atlantic. The first relates to the initial period of Dutch commercial expansion in the Atlantic, which was dominated by a system of open trade, in which all merchants from the Dutch Republic were allowed to participate in Dutch activities in the Atlantic. After the establishment of the WIC, Dutch trade in the Atlantic became a monopoly, with private merchants prohibited from trading on the western coast of Africa and other areas of the Atlantic Ocean, and were granted a period of two years to remove all their assets and personnel from various commercial posts. The two decades following the enforcement of the WIC monopoly (1624) corresponded in fact to the period of major military expansion of the Dutch in the Atlantic, visible with the takeover of several trading posts, forts and settlements from the Portuguese. By the end of the 1640s, the Dutch WIC would suffer a major blow with the loss of São Tomé, Angola and Dutch Brazil, and the participation of the Company and the Republic's private merchants in the Atlantic economy would take a different form. The initial role played by the islands off the coast of the African continent would be completely overshadowed by the key position that Elmina and, later, the Loango Coast would assume.

Our argument is based on information gathered from the notarial records of Amsterdam, deposited in the City Archive, ${ }^{6}$ the documentary collections of the first and second WIC housed in the Netherlands National Archive, as well as data obtained from several published journals of voyages ${ }^{7}$ and other edited collections of Dutch source

6. Our analysis of the role of the African islands in the early period of formation of the Dutch Atlantic is based on a set of 341 notarial contracts. This set comprises all notarial contract regarding business activities of Amsterdam merchants with the western coast of Africa for the period of 1580 to 1674 . This set is part of a bigger sample comprising c. 17.000 notarial contracts covering the Atlantic, the Baltic and the Mediterranean between 1580 and 1750 . The data sample has been gathered by Cátia Antunes and Filipa Ribeiro da Silva over the past decade.

7. Henk den Heijer, ed., Expeditie naar de Goudkust: Het journaal van Jan Dircksz Lam over de Nederlandse aanval op Elmina, 1624-1626 (Zutphen, 2006); Henk den Heijer, ed., Naar de koning van Dahomey: Het journaal van de gezantschapsreis van Jacobus Elet naar het West-Afrikaanse koninkrijk Dahomey in 1733 (Zutphen, 2000); Albert van Dantzig, ed., The Dutch and the Guinea Coast, 1674-1742: A collection of documents from the General State Archive at The Hague (Accra, 1978); Albert van Dantzig and Adam Jones, eds., Pieter de Marees: Description and historical account of the Gold Kingdom of Guinea (1602) (Oxford, 1987); J.D. La Fleur, ed., Pieter van den Broecke's journal of voyages to Cape Verde, Guinea, and Angola, 1605-1612 (London, 2000); Adam Jones, ed., Olfert Dapper's description of Benin (Madison, 1998); Adam Jones, ed., West Africa in the mid-seventeenth century: An anonymous Dutch manuscript (Atlanta, 1995); Adam Jones, ed., Brandenburg sources for West African history, 1680-1700 (Stuttgart, 1985); Adam Jones, ed., German sources for West African history, 1599-1669 (Wiesbaden, 1983). 
materials. ${ }^{8}$ We start by considering the role played by these islands in the initial period of formation and operationalization of Dutch commercial circuits in the Atlantic. Here, we pay special attention to three themes: i) the function of these islands on the definition of the Dutch inter-continental commercial circuits south of Iberia and Gibraltar; ii) their role on the organisation of Dutch coastal circuits in western Africa; and iii) the establishment of Dutch connections in the South Atlantic. A brief analysis of the geo-strategic importance of these islands for the achievement of the military ambitions of the States General of the Dutch Republic and the WIC in the South Atlantic will follow. But let us start by describing the geographical location and environmental conditions of these islands and assessing the influence of these natural factors on local economic activities.

\section{Geography and resource endowments}

The island of Arguin is located off the western coast of Mauritania, in a bay named after the island. Throughout the early modern period, Arguin owed its economic importance to its strategic position close to the African coast, and its easy access to the trans-Saharan commercial circuits. Together, these factors helped make Arguin a gateway for African slaves and products, including gold and Arabic gum. Its location and gateway role led to continuous disputes between European sea powers eager to assume control over it. The Portuguese were the first to establish a trading post on the island. ${ }^{9}$

Like Arguin, the island of Gorée had virtually no local production. Its position close to the continent, more precisely the Peninsula of Cape Verde, and its close links to the trading centres along the Petite Côte of Senegal and their extended commercial networks inland covering a substantial part of the Senegambia region, afforded the island a significant role in the Atlantic economy. ${ }^{10}$ The island would emerge as a trading centre for several African products including hides, rice, beeswax and grain, and for the human trafficking in enslaved Africans. However, it must be emphasized that the island did not play a major role as a slave port and never became a leading export centre for African products. The Portuguese were the first to have a small settlement in the island in 1444; however, as in the case of Arguin, their rule would be disputed by other European states and state-sponsored companies.

8. Louis Jadin, ed., L'Ancien Congo d'après les archives romaines (1518-1640) (Bruxelles/ Rome, 1954); Louis Jadin, ed., L'Ancien Congo et l'Angola, 1639-1655: D'après les archives romaines, portugaises, néerlandaises et espagnoles, 3 vols. (Bruxelles/Rome, 1975); Klaas Ratelband, ed., Vijf Dagregisters van het kasteel São Jorge da Mina (Elmina) aan de Goudkust (1645-1647) ('s-Gravenhage, 1953).

9. J. Bato' Ora Ballong-Wen-Mewuda, 'A instalação de fortalezas na costa Africana: Os casos de Arguim e da Mina: Comércio e contactos culturais', in Luís de Albuquerque, ed., Portugal no Mundo (Lisboa, 1989), II, pp.137-49; Susanne Daveau, 'Organização do espaço de Arguim à Serra Leoa e a sua progressiva descoberta pelos Portugueses na segunda metade do século $\mathrm{XV}$, in Congresso Internacional Bartolomeu Dias e a sua época: actas (Porto, 1989), III, pp.125-42.

10. George E. Brooks, Eurafricans in western Africa: Commerce, social status, gender, and religious observance from the sixteenth to the eighteenth century (Athens, 2003). 
The archipelago of Cape Verde, on the other hand, comprises 10 islands divided into two groups: the windward and leeward islands. The former group includes Santo Antão, São Vicente, Santa Luzia, São Nicolau, Sal and Boavista, whereas Maio, Santiago, Fogo and Brava are part of the latter group. Due to their resource endowments and climatic conditions, the islands in these two groups had very different economic interests, with some, like Santiago and Fogo, suited to arable agriculture, and others, such as Maio and Sal, more amenable to cattle breeding and salt production. From the first Portuguese settlement on Santiago, the Crown granted settlers permission to trade in the aforementioned areas in the mainland in order to stimulate economic growth in the Cape Verde islands. As early as the mid-fifteenth century, the islanders' production of salt and cotton cloths was finding its way to the coast, together with other commodities, often of European origin, to be bartered for slaves, ivory and foodstuffs, such as maize and rice. Most of the enslaved Africans and elephants' tusks imported into the Cape Verde islands, in particular Santiago, were then re-exported to the international consumption markets, mainly to Portugal, Spain and the Canary Islands and from there often re-exported to the Spanish American colonies. Foodstuffs, on the other hand, were consumed in the Archipelago and partially used to supply the vessels operating in the long-distance trades. Over time, the islands would emerge as an entrepôt between the coastal and longdistance commercial circuits. ${ }^{11}$

Further south in the Gulf of Guinea, on the Equator, lies the archipelago of São Tomé, which comprises four islands: São Tomé, Príncipe (present-day São Tomé and Príncipe), Fernão Pó and Annobon (present-day Equatorial Guinea). As in the case of Cape Verde, these islands were home to different economic activities and there were economic exchanges to be had among them. São Tomé was mainly dedicated to the production of sugar, although cotton, ginger, maize, rice, coconuts and orchards of oranges, lemons, limes, bananas and fig trees were also cultivated. The settlers also grew various types of vegetables and beans, and kept cattle, pigs, sheep, goats and poultry. These products were used for local, coastal and long-distance consumption. From the beginning of Portuguese settlement, the islands had been connected to a wide number of ports on the adjacent African coast. In these ports, settlers and merchants based in the islands of São Tomé and Príncipe acquired slaves, beads and various other African products. Some of the slaves were kept on the islands - mainly in São Tomé - to meet the labour needs created by the deforestation process and subsequent sugar cane cultivation and sugar production. Other slaves were imported into the islands, only to be re-exported to the Portuguese fortress-ports on the Gold Coast as well as to European and American labour markets. $^{12}$

11. Maria Manuel Torrão, 'Actividade comercial externa de Cabo Verde: organização, funcionamento, evolução’, in Luís de Albuquerque and Maria Emília Madeira Santos, eds., História geral de Cabo Verde (Lisboa/Praia, 1991), I, pp.249-55. Maria Manuel Torrão, 'Rotas comerciais, agentes económicos e meios de pagamento', in Maria Emília Madeira Santos, ed., História Geral de Cabo Verde (Lisboa/Praia, 1995), II, pp.17-123. André Pinto de Sousa Dias Teixeira, A ilha de São Nicolau de Cabo Verde nos séculos XV a XVIII (Lisboa, 2004).

12. Cristina Maria Seuanes Serafim, As ilhas de São Tomé no século XVII (Lisboa, 2000); Carlos Agostinho das Neves, S. Tomé e Príncipe na segunda metade do século XVIII (Lisboa, 1989); 


\section{The role of African islands in the development of the Dutch Atlantic}

The islands off the coast of western Africa were strategically and economically important to European states, chartered companies and private merchants operating in this region of the world. Both Arguin and Gorée suffered multiple naval attacks as the European powers sought to exercise control over the islands. Throughout the early modern period, possession of Arguin changed hands at least five times, between Portuguese, Dutch, English and French authorities (see Table 1). The same was true of Gorée, where jurisdiction over the islands was disputed by the Portuguese, Dutch, English and French (see Table 2). Naval attacks and failed attempts to take over islands from other European sea powers were also a common practice. Both Cape Verde and São Tomé, in particular their main ports, were attacked by several naval expeditions, as Portuguese control over the archipelagos was on several occasions disputed by other Europeans, primarily the Dutch and English. ${ }^{13}$

In the Gulf of Guinea, Dutch forces tried three times to take over the islands of São Tomé and Príncipe: the first assault, in 1597-1598, was initiated by Balthasar de Moucheron, a Flemish merchant based in the Dutch Republic; ${ }^{14}$ the second attempt, led by the States General of the United Provinces of the Netherlands, occurred in the following year; ${ }^{15}$ and the third was conducted under the command of Count Mauritis of Nassau, governor of Dutch Brazil, on behalf of the first WIC and the States General, in 1641. ${ }^{16}$ Such violent encounters raise important questions. Why did naval powers aim at controlling these islands? What did the islands offer that locations on the western coast of Africa could not, or, in other words, what were the advantages of being based on islands rather than on the continent? By analysing these issues, we can identify the roles of the islands off the western coast of Africa in the process of European maritime expansion, the consolidation of European political dominance in these regions and the shaping of the Dutch maritime economy in the Atlantic.

Isabel B. de Sá-Nogueira and Bernardo de Sá-Nogueira, 'A ilha do Príncipe no primeiro quartel do século XVI: Administração e comércio', Congresso Internacional Bartolomeu Dias e a sua época (Porto, 1989), III, 85-6; Jorge de Faro, 'Organização comercial de S. Jorge da Mina em 1529 e as suas relações com a ilha de S. Tomé', Boletim Cultural da Guiné Portuguesa, 13, No. 51 (1958), pp.305-63; John Vogt, 'The early São Tomé-Príncipe Slave Trade with Mina, 1500-1540', The International Journal of African Historical Studies, 6, No. 3 (1973), pp.453-67; John Vogt, Portuguese rule on the Gold Coast 1469-1682 (Athens, 1979); John Vogt, 'Notes on the Portuguese cloth trade in West Africa, 1480-1540', The International Journal of African Historical Studies, 8, No. 4 (1975), pp.623-51.

13. Artur Teodoro de Matos, 'Santo Antão de Cabo Verde (1724-1732): da ocupação inglesa à criação do regime municipal: Mutações políticas, recursos económicos e estruturas sociais', in A dimensão atlântica de África: II Reunião Internacional de História de África. Rio de Janeiro 30 de Outubro a 1 de Novembro de 1996 (São Paulo, 1997), pp.187-202.

14. Jones, German Sources, p.9.

15. Jones, German Sources, p.9.

16. Jones, German Sources, pp.74, 132. 
Table I. Arguin: changes in political control.

\begin{tabular}{ll}
\hline Period & Dominant European power \\
\hline $1544-1633$ & Portuguese Crown \\
$1633-1665$ & Dutch Republic \\
1665 & English Crown \\
$1665-1678$ & Dutch \\
$1678-1685$ & French (abandoned) \\
$1685-1721$ & Brandenburg - Prussia \\
$172 \mid-1722$ & France \\
$1722-1724$ & Dutch Republic \\
$1724-1728$ & France \\
$1728-19$ th century & Local tribal chiefs \\
19 th century & France \\
\hline
\end{tabular}

Table 2. Gorée: changes in political control.

\begin{tabular}{ll}
\hline Period & Dominant European power \\
\hline $1444-1588$ & Portuguese Crown \\
1588 & Dutch Republic \\
$1588-162 \mid$ & Portuguese Crown \\
$162 \mid-1663$ & Dutch Republic \\
$1663-1664$ & English Crown \\
$1664-1677$ & Dutch Republic \\
$1677-1960$ & France \\
\hline
\end{tabular}

For the first sailors and merchants travelling to western Africa, uninhabited islands such as Arguin, Gorée, Cape Verde and São Tomé provided a safe haven where no negotiation and/or conflict with African authorities was required either for the use of the islands as refreshing stations, using the natural resources of the land (water, firewood, fruits, etc.), or for settlement. Abundance of water, wood and land also made some of these islands (especially in the Cape Verde and São Tomé archipelagos) attractive for agriculture, cattle breeding, and extraction of natural resources such as salt. Their proximity to the African mainland was also attractive to merchants, as it could allow for profitable transactions. Over time, the islands' ports would become important centres for the coastal trade. Given the maritime nature of European expansion into the Atlantic (as well as in Asia), islands with their natural harbours and strategic positions in relation to the oceanic wind systems would also be ideal ports of departure and call for vessels operating in long-distance circuits. These factors were certainly taken into account by Portuguese sailors and merchants when they built their first settlements on islands along the western coast of Africa rather than on the mainland. Similar advantages were also foreseen by other European merchants, chartered companies and states, leading to multiple attempts to defy and undermine Portuguese control over these islands. 


\section{West African islands and the expansion of Dutch shipping}

As had been the case earlier for the Portuguese, and would later apply to other European traders operating in the Atlantic, for both private merchants based in the Dutch Republic and later for the WIC, islands off the coast of Africa offered two main advantages from a navigational point of view. First, they were excellent ports of call for vessels sailing either to western Africa or further south. Accordingly, ships departing from Amsterdam, Texel, Flushing, Rotterdam and other Netherlandish ports for the western coast of Africa and to other destinations in the South Atlantic often called at the islands. In the open Atlantic, the ships often called at Madeira and the Canaries, as well as the Cape Verdean islands least populated and least controlled by the Portuguese, that is, Maio, Sal, Santo Antão and São Vicente. The stop at Madeira, the Canaries and Cape Verde was used to load the ships with fresh water and foodstuffs and to store extra reserves of firewood. For instance, surgeon Samuel Brun on his first voyage to Loango and Congo in 1611-1613 on board the ship Meermann under the command of skipper Jan Pieterssen, called at the Cape Verdean islands of Sal, Maio and Brava to stock up on fresh water, and answer to 'other necessities'. ${ }^{17}$ These islands were used as port of call not only by private ships from the Republic, but also to vessels and fleets organized by the States General and the WIC. For example, Lance-Corporal Johann von Lübelding, serving in the force despatched by the States General to take the island of São Tomé in 1599, reported that the fleet called at the islands of São Nicolau and Maio to obtain fresh water, meat (mainly birds caught by crew members and soldiers on board) and salt. ${ }^{18}$

Second, the islands were excellent bases for the formation and departure of convoys. For vessels sailing under Dutch flag, and later under the WIC's flag, it was common to sail in convoy either on their voyages to western Africa and other Atlantic regions as well as on their return voyages to Europe. The convoys were organized at strategic points along the coast, and some African islands played an important function in this respect. The island of Gorée was one of these strategic places. Ships operating between the Republic, Cape Verde and the Petite Côte of Senegal usually formed convoys there. The ship Roode Haart and the vessels of Master Pieter Cornelissen Spelman from Rotterdam are good examples of these practices. In 1606, they departed in convoy from the island of Gorée after fetching water and victuals. ${ }^{19}$

The establishment of the WIC by the States General in 1621 did not bring major changes in the use of islands as strategic points in the inter-continental trade. Company ships heading to the South Atlantic continued to anchor temporarily at several ports along the coast, especially the ports of the island of Arguin, Gorée and São Tomé. Between the Republic and Cape Verde Peninsula the vessels would sail in open water, calling at the Canary Islands. At the island of Gorée, the Company vessels would unload soldiers, provisions and ammunition to supply the garrison living in the fort, as well as products to barter for African goods. At the same time, the African commodities purchased in by Company servants living in the castle would be loaded on board. From

17. Jones, German Sources, pp.46-63.

18. Jones, German Sources, pp.9-17.

19. La Fleur, Pieter van den Broecke's Journal, p.34. 
Gorée, ships would then sail further south, touching at several places in Sierra Leone and on the Grain Coast, before anchoring at Elmina. For instance, the ship De Haarlem, 200 last ${ }^{20}$ and 26 cannon, under the command of Sijmon Hoen, left Elmina on 19 January 1645 with a cargo of ' 1,702 marks, 2 ounces $83 / 4$ engels of gold, $19.550 \mathrm{lb}$. of ivory and 55 people on board, including 15 soldiers and 2 sergeants who had completed their term of service', and sailed to the Republic via São Tomé and Brazil. ${ }^{21}$

When the WIC exercised monopoly rights over the Dutch Atlantic trade, especially in the 1630s and 1640s when its naval power and control over territories on the South Atlantic reached its zenith, the island of São Tomé in the Gulf of Guinea performed an important role as port of call for the Company's vessels on their return voyage to Europe or Dutch Brazil. Goldsmith Michael Hemmersam, from Nuremberg, serving the WIC in Elmina in the $1640 \mathrm{~s}$, gave a clear image of this practice while reporting on his return voyage to Europe at the end of his term of service. He wrote:

On 15 January 1645, I again embarked on a ship, to come home from this country. When we were aboard and everything had been loaded, we sailed in God's name to the island of São Tomé, $[\ldots]$. After nine days we cast anchor and went ashore to deliver the letters we had with us. ${ }^{22}$

\section{The benefits of West African islands for Dutch trade}

From a commercial point of view, the islands of Arguin, Gorée, Cape Verde and São Tomé played an important role in the formation of the Dutch trading circuits, initially through the initiative of private merchants and later of the WIC. Islands played a key function both in the long-distance and the coastal African trades, either as main gateways for the export of products for international consumption and labour markets, or as logistical hubs in the coastal trade. In the early stages of the trading relationship between the Dutch Republic and western Africa, islands like Gorée and some of the least populated islands of Cape Verde were pivotal for the organization of the coastal trade with nearby regions on the mainland.

Until the early seventeenth century, the ships freighted in the Dutch ports to conduct trade between the Republic and western Africa were the same ones that carried on the coastal trade in a system of port-to-port commerce. These coastal routes started at strategic points along the coast, two of them being the islands of Arguin and Gorée. Vessels operating on the Republic-Cape Verde Peninsula-Republic route would approach the coast at the latitude of Gorée. From there, the ships would proceed further south, sailing port-to-port along the Petite Côte of Senegal. For instance, the ship Roode Hart, freighted by Elias Trip for a trading voyage between Holland and Cape Verde, departed from Dordrecht in November 1605 under the command of Paulus Theunissen of Rotterdam. Once Cape Verde was in sight, the vessel approached the island of Gorée and from this point onwards started to navigate port-to-port in order to trade along the shore with local

20. - old Dutch measure of volume for ship's capacity and tonnage. 1 last $=2$ tonnes.

21. Jones, German Sources, pp.97-133.

22. Jones, German Sources, p.131. Ratelband, Vijf dagregijsterds, I, p.159 
people. The vessel conducted trade in Gorée, Portudal, Rufisque and Joal, in present-day Senegal. ${ }^{23}$

Some commercial trips heading further south, such as those bound for the coast of Angola, also approached the coast at the same points and started to conduct trade at the islands of Arguin or Gorée. For example, the Neptunnis, which departed Texel on November 1607 under the command of Master Aris Janssen from Schans, approached the coast at Cape Blanco, near the island of Arguin, and sailed close to the coast, conducting trade at Rufisque and Portudal. From here, the crew set sail towards the south coming closer to the coast at the latitude of Cape Palmas, and thereafter sailed in cabotage, anchoring at the roadsteads of Cape Appolonia, Cape Three Points, Komenda, Cape Coast, Cape Lopez, Loango and the Congo River. ${ }^{24}$

The practice of combining long-distance routes and coastal circuits increased the length of voyages as well as the costs of wages, victuals and insurance, while at the same time postponed and sometimes reduced return profits. Merchants and trading companies in the Republic were, since the early years of trade with western Africa, keen on finding ways to split the two sets of circuits. In the process, islands such as Gorée, as well as some islands in the Cape Verde archipelago, acquired important logistical functions. These territories became key points for assembling small sloops ${ }^{25}$ (barges) to be used in the coastal trade. For example, in 1603, two vessels in the service of the Guinea Company (Compagnie van Guinee), which had departed from Amsterdam to Cape Verde and the Gulf of Guinea, carried on board a prefabricated sloop, which was put together near the Cape Verde Peninsula, most likely on the island of Gorée. ${ }^{26}$ The optimality of Gorée and the sparsely inhabited islands of Cape Verde for such operations is clearly explained by Pieter de Marees in his Description (1602):

[...] on these islands no people live at all and all there is to be had is an abundance of ballast and firewood. But there is a good valley here for putting together sloops, the place is much used for this purpose and therefore many ships visit it. ${ }^{27}$

Several African islands also played an important role in the Dutch long-distance trade, given their production of commodities in demand in the European markets, including sugar, hides, and so on. From as early as the 1590s, private merchants based in the Dutch Republic therefore carried out regular trade in some of these products. In 1591,

23. La Fleur, Pieter van den Broecke's Journal, pp.23-42. Multiple examples of this practice can be found in the collection of the Notarial Archives of Amsterdam (SAA); see, for example, Not. Arch. 117/22: 19 September 1609; Not. Arch. 128, 19 September 1612; Not. Arch. 62/217v: 14 January 1611; Not. Arch. 253/476v: 13 April 1612.

24. La Fleur, Pieter van den Broecke's Journal, pp.43-67. See also: SAA, Not. Arch. 196/235v236: 7 March 1609; Not. Arch. 107/66-66v: 27 June 1607; Not. Arch. 138/7: 4 September 1614.

25. Sloop (translation from the Dutch sloep). In this context it refers to barges; that is, vessels designed to navigate in rivers, canals and shallows waters.

26. Jones, German Sources, p.20.

27. Dantzig and Jones, Pieter de Marees, pp.8-10. 
for instance, Pieter van de Moere, merchant in Amsterdam, appears to have been associated with Gonsalo Alfonso Mayo from Portugal in the import of sugar from São Tomé to Amsterdam, using the services of skipper Jan Pieterssz and his vessel Den Salvador. ${ }^{28}$ Other cases in point are Garpar Sanches and Gaspar Nunes, Portuguese merchants based in Amsterdam. In the 1610s, both were participating actively in the import of hides from the islands of Cape Verde to the ports of Amsterdam and Rotterdam. ${ }^{29}$

During the early years of Dutch commercial expansion in the Atlantic, preceding the establishment of the WIC, the islands off the coast of Africa also appear to have played a role in the acquisition of slaves for export to Iberia and to the Spanish American colonies. From the 1590 s to the 1620 s, members of the mercantile community of the Republic appear in various notarial contracts engaged in this type of activity. This involvement in the slave trade could be direct. In 1596, for instance, Cornelis Jan Boer, inhabitant of Amsterdam and skipper of De Fortuyn, transported 58 slaves from the island of São Tomé to Lagos in Portugal on the account of António Soares de Lamego, merchant in Lisbon. ${ }^{30}$ However, during this early period, the participation of Dutch merchants in the slave trade between the African islands, Iberia and/or the Americas appears largely to have taken an indirect form, through the provision of insurance for vessels and cargoes. In 1617, for example, Duarte Fernandes, merchant of the Portugese Natie of Amsterdam obtained for Simão Pereira, merchant in Madrid, an insurance for different goods valued at 5,000 pounds for the voyage of the Nossa Senhora do Amparo e Santo António between Lisbon, Ardra, São Tomé and New Spain. ${ }^{31}$

After the chartering of the WIC by the States General, islands continued to be key ports for the logistical operations of the Company, with Arguin, Gorée and São Tomé remaining paramount in these activities. ${ }^{32}$ Michael Hemmersam, cited earlier, offers us valuable information on the role of different islands off the western coast of Africa for the Company. With regard to the island of Gorée, he reports:

Every year a ship is sent there to trade with the Moors. There is a castle in the country/land, built on a high hill on account of the Moors, who often show themselves to be refractory. They once cause havoc there and killed all Dutch people that were in the country/land. ${ }^{33}$

Hemmersam also informs us that further south in Sierra Leone 'on the island Solion, resided a merchant sent by the West India Company to conduct trade continuously with

28. SAA, Not. Arch. 42/13v: 21 August 1591. For other examples, see: SAA, Not. Arch. 71/196v: 9 February 1596; Not. Arch. 33/376v: 16 March 1600; Not. Arch. 58/288v: 14 February 1609; Not. Arch. 629/2v: 19 November 1621.

29. SAA, Not. Arch. 115/22-23: 19 September 1609; Not. Arch. 117/22: 19 September 1609; Not. Arch. 62/210v: 24 December 1610; Not. Arch. 62/195v: 30 September 1610; Not. Arch. 125/27v-28v: 27 April 1611; Not. Arch. 124/131-131v: 5 August 1611.

30. SAA, Not. Arch. 83/165-165v: 6 May 1599.

31. SAA, Not. Arch. 624/155v: 3 November 1617; Not. Arch. 611A/421: 20 June 1618.

32. Ratelband, Vijf dagregijsters, Introduction.

33. Jones, German Sources, 98. 
the Moors of the country'. ${ }^{34}$ The same was also true of the Angolan coast. In the $1640 \mathrm{~s}$, the factor Pieter Zeegers and his assistant Ferdinand van Capelle were in charge of two warehouses of the Company located in the Congo River in the island of Boma. ${ }^{35}$

During Dutch rule over Brazil, the islands off the coast of western Africa also became important bases for the supply of African slave labour to plantations in the colony, as well as African products like ivory and wax, part of which remained in Dutch Brazil for local consumption, with the remainder being re-exported to northern European markets. Thus, after the WIC assumed control of the north-eastern captaincies of Brazil, several long-distance routes were established directly between the colony and the islands off the African coast, especially Gorée. In the 1630s, the Pernambuco- Gorée-Pernambuco route was regularly sailed by Company vessels. ${ }^{36}$ In the following decades, and as late as the 1760s, Gorée continued to play a role in Dutch long-distance trade, particularly the trans-Atlantic trade, as evidence gathered in the Transatlantic Slave Trade Database shows. ${ }^{37}$

Between 1641 and 1648, the Company also promoted important direct routes between the Republic and the island of São Tomé. These routes had two main functions; first, to supply provisions, ammunition and foodstuffs to the military and civilian staff of the Company based there; and second, to ship the local production of sugar, together with enslaved Africans and African products purchased in the nearby coastal areas, to the Republic. However, given the fact that the main 'product' — slaves — was for 'consumption' in the Brazilian market, the routes to Europe never became so significant. Instead, return voyages to Europe often proceeded via Brazil, where the slaves were unloaded and the cargoes completed with Brazilian sugar, dyewood and tobacco. ${ }^{38}$

In the second half of the seventeenth century, these islands lost most of their initial importance in the Dutch maritime enterprise. As the WIC managed to take hold of possessions on the mainland, namely on the Gold and Slave Coasts, the Bight of Benin and in Loango, and obtain direct access to the African outlets of products and human resources in demand in the European and American markets, the islands lost their key roles. This shift from island-based navigation and trade to mainland-based activities had also occurred in the case of the Portuguese Empire in the mid-sixteenth century. As soon as the Portuguese managed to settle and consolidate their presence in the Upper Guinea coast and the Angolan coast, the archipelagos of Cape Verde and São Tomé lost most of their economic importance.

34. Jones, German Sources, p.98.

35. Netherlands National Archive (NA), OWIC 46, 'Letter from Pieter Zeegers to the Chamber of Zeeland', 6 May 1641; OWIC 56K, 'Brief description [...] in the Kongo River by Cornelis Jansen Root'; OWIC 56, 'Letter from Cornelis Hendricksz. Ouwman', 2 March 1641. See also Ratelband, Os Holandeses no Brasil, pp.123, 184, 269.

36. Ratelband, Vijf dagregijsters, Introduction.

37. http://www.slavevoyages.org, 21-12-2013. See, for instance, voyages no. 44254, 44163, 44174, 44183, 11501.

38. Ratelband, Vijf dagregijsters, Introduction. For further information on the slave trade conducted under the Dutch flag from São Tomé in the 1640s, see: http://www.slavevoyages. org: 20-12-2013. See, for instance, voyages no. 11325, 11322, 11323, 11324, 11321, 11311, 11601,44142 . 


\section{The West African islands and Dutch political sovereignty}

Alongside their naval and commercial functions, islands were often regarded as strategic locations, from which to claim and consolidate jurisdiction and sovereignty over neighbouring lands and surrounding seas. This was especially important in the early modern period, an era of naval warfare between expansionist European states. As early as the fifteenth and sixteenth centuries, the Portuguese and Spanish had been struggling for the control of the Atlantic archipelagos. By the late sixteenth century, when the Dutch entered the competition for overseas trade, the States General of the Dutch Republic would follow a broadly similar approach.

In 1597-1598, merchants based in the Republic attempted for the first time to establish a post in western Africa, in the archipelago of São Tomé and Principe, by taking over the island of Principe from Portuguese control. A fleet organized and equipped under the leadership of Balthasar de Moucheron, attacked the island and seized control of it for several months. However, disease among crew members and the resistance offered by a Portuguese force sent to the island, condemned the expedition to failure. ${ }^{39}$

The disaster of this first expedition did not dissuade De Moucheron and his fellow merchants from their plan to establish a trading post in the region. To this end, they lobbied the States General to organize a naval expedition to capture the main island of the archipelago, São Tomé. In May 1599, a fleet with 6,000 sailors and 2,000 soldiers departed for the island under the command of Pieter van der Goes. ${ }^{40}$ As in the previous expedition, the Dutch commanders were able to take over the island (at least its main port), and drive the Portuguese settlers to take refuge inland. Within a few weeks, however, many of the sailors and soldiers fell victim to tropical diseases, and again, the expedition resulted in total failure. The military were forced to abandon the main port of the island, leaving it to the Portuguese settlers, and on the return voyage to the Republic most of the gains from the plunder of the island were lost in a storm. ${ }^{41}$

If we analyse this expedition in the light of the on-going Eighty Years War between the Republic and the Habsburg empire, it is not surprising that as early as 1599, the States General of the United Provinces, following up on an earlier expedition organized by private actors, took the initiative in financing and despatching a fleet to take the island of São Tomé from the Portuguese Crown. Even less surprising is the fact that although the naval expedition to São Tomé turned out to be a massive failure, the States General did not give up on the idea of creating a military base in the southern hemisphere to make a stand against the Habsburg empire in the region and defend the interests of Dutch traders operating in the gulf of Guinea. The States General's ambition would be fulfilled in 1612 with the construction of Fort Nassau in Mouri (present-day Ghana). ${ }^{42}$

39. Jones, German Sources, p.9.

40. Antonio Rumeu de Armas, La Invasión de Las Palmas por el Almirante Holandés van der Does en 1599 (Las Palmas, 1999).

41. Jones, German Sources, p.9.

42. J.K.J. de Jonge, De Oorsprong van Nederland's Bezittingen op de Kust van Guinea in herinnering gebracht uit de oorspronglijke stukken naar aanleiding van een voorgenomen afstand dier bezittingen aan Groot-Britannië ('s-Gravenhage, 1871), pp.16, 40-3. 
The attempts of the States General to increase its sovereignty and jurisdiction in the Atlantic in the context of the war with the Habsburg monarchy did not end there. From the early 1600s onwards, several businessmen from the Republic, including both Dutch and foreign merchants, operating in areas of Western Africa which were under the military control of the Portuguese Crown, such as the Gold Coast, had advocated the establishment of a commercial company with a monopoly over the Atlantic trade. Although numerous Dutch businessmen engaged in trade in the same areas and other Atlantic regions such as Brazil strongly opposed this idea, in 1606, the creation of a monopoly company began to be discussed in the assembly of the States General. On 3 June 1621, when the States General accepted the proposal of the States of Holland and chartered the Dutch WIC, the Company became a reality.

In 1624, as the Company commenced its activities, Fort Nassau (in Mouri) was transferred to its direct administration, and soon after the WIC started a series of military initiatives to take over several territories under the control of the Portuguese in the Atlantic, including various islands, namely Gorée, Arguin and São Tomé. The islands came under the control of the Company, and the jurisdiction and sovereignty of the States General, in 1624, 1633 and 1641, respectively. The Company's takeover of the islands was followed by the establishment of a political, military and commercial administrative structure. Within this organization the highest representative of the Company in the islands was not only authorized to impose the jurisdiction of the WIC in nearby regions, but was simultaneously the representative of the States General of the Dutch Republic, often holding diplomatic prerogatives to claim the sovereignty of the States General, and to engage in negotiations with the representatives of African and other European authorities.

The Company's administrative apparatus in the islands and the nearby regions was organized according to the managerial and administrative structure of the Company. Accordingly, jurisdiction over the different territories was divided among the Board of Directors, also known as Gentlemen Nineteen, and the five Chambers-Amsterdam, Zealand, Maas (Rotterdam), Friesland and Northern Quartier - and the Chamber of 'City and surrounding land' (Groningen). Accordingly, the Cape Verde region, including the island of Gorée and the several trading posts in the Petite Côte of Senegal, came under the control of the Chamber of Amsterdam. The Chamber of Zealand was in charge of Arguin and the surroundings of Cape Blanco, while the area of the Sierra Leone estuary was the responsibility of the Chamber of the Maas. ${ }^{43}$

Taken over by Admiral Jol in 1641, with an expedition sent from Dutch Brazil, the island of São Tomé fell initially under the jurisdiction of the central government of that colony. Due to the economic potential of the island's sugar production, jurisdiction over this territory and the organization of its government was marked by several disputes within the Company. By 1642, a commission called by the WIC to analyse and deliberate on this matter submitted recommended to the States General that the government of São Tomé (like the one of Angola) was to be detached from the jurisdiction of the Central

43. Filipa Ribeiro da Silva, Dutch and Portuguese in Western Africa: Empires, Merchants and the Atlantic System, 1580-1674 (Leiden, 2011), pp.27, 72. 
Government of Brazil. The States General then established a new administrative division for the WIC posts in western Africa. According to this new organization, the west coast of Africa was to be divided into two districts with separate governments: the northern and southern district, with the islands in the Gulf of Guinea included in the latter. ${ }^{44}$ Instead of following the orders of the States General, the Board of Directors decided to establish a third district with its own government in São Tomé. In their understanding, the island was to play an important role as a bridge between the two other districts. This third district did not last long, however, and by 1645 the islands of São Tomé were incorporated into the Northern district, though they retained their own government. ${ }^{45}$

Within this administrative, military and commercial framework, each island under Company rule had its own government, often with some jurisdiction over the neighbouring areas, although in most cases only nominally. In the case of Gorée and Arguin, there was a commander responsible for the garrison, and a chief merchant in charge of the trade. The former had jurisdiction over military matters and personnel, and the latter over the commercial staff and their activities. The governments at Fort Gorée and Fort Arguin were under the supervision of the Chambers of Amsterdam and Zealand, respectively, as mentioned earlier. ${ }^{46}$ Between 1641 and 1648, São Tomé was administrated by a director, who was responsible for the commercial activities of the Company in these areas. Under his supervision was the head factor of the Gulf of Guinea, who managed the activities of the factors, sub-factors and assistants under their jurisdiction. Besides the Company employees responsible for the organization of trade, the WIC also appointed officials to supervise its commercial monopoly. These officials, called fiscals, were placed in the most profitable areas: the island of São Tomé was one of them. ${ }^{47}$ Around 1643, the highest representatives of the company in the island were Jan Triestand, director of the trade, and Willem Jansz van Meeckeren (or Megeren) the head factor of the Gulf of Guinea, who was based on the island. Two years later, Jan Mulders (or Molders) was the director of São Tomé (responsible for all matters) and Hasenbergh was the general factor. ${ }^{48}$

Islands off the coast of western Africa, like isles in other parts of the globe, appear therefore to have been used by states and state-sponsored companies as points of departure to build and consolidate commercial monopolies, naval power and political sovereignty.

\section{Epilogue}

By the late sixteenth and early seventeenth centuries, the advantages offered by islands to European maritime exploration into the Atlantic and the Indian oceans were well

44. NA, SG, 5773, 'Les XIX aux États-Généraux' 19 March 1642; Jadin, L'Ancien Congo et l'Angola I, pp.250-1; Ribeiro da Silva, Dutch and Portuguese, p.36.

45. NA, OWIC 9, 'Les XIX aux directeurs de Loanda' 14 June 1642; Jadin, L'Ancien Congo, I, pp.296-302.

46. SAA, Not. Arch., 2791/549: 11 October 1669; Not. Arch. 2791/709: 24 October 1669; Ribeiro da Silva, Dutch and Portuguese, p.31.

47. Ribeiro da Silva, Dutch and Portuguese, p.43.

48. Ratelband, Os Holandeses no Brasil, 2003, pp.211-4, 247, 279. 
known. As a consequence, northern European explorers and merchants, then starting to sail south of the Tropic of Cancer under their own initiative or under the sponsorship of European states, would dispute with the Portuguese the control of these territories. The States General of the United Provinces of the Netherlands, the private merchants based in the Republic and later the WIC were cases in point. Starting their sailing and commercial ventures along the western coast of Africa roughly 150 years later, they would attempt several times to take over islands from the Portuguese, either on their own initiative or with the formal support of the States General.

The evidence presented in this study clearly shows that in the initial period of Dutch expansion in the Atlantic between the 1590s and 1640s, islands offered multiple benefits to the merchants of the Republic, the WIC and the States General, not only for navigation and trade, but also in their attempts to impose a commercial monopoly and extend their sovereignty over new territories and seas. From both a nautical and commercial point of view, the use of islands - as refreshing stations, ports of call, and logistical foci for the long-distance and coastal trade — was paramount for the setting up of the Dutch Atlantic economy. The islands off the west coast of Africa also proved to be important centres for enforcing the power of the Company and the sovereignty of the States General of the Republic in the Atlantic, especially during the rule of the first WIC (1621-1674).

Daily life in these islands was not, however, simply marked by disputes and warfare. Even during the periods of conflict between the major European sea powers of the early modern period, there was room for peaceful exchange and cooperation between sailors and soldiers fighting on opposite sides. Michael Hemmersam, goldsmith from Nuremberg in the service of the WIC in Elmina, while calling at the island of São Tomé in 1645 on his end-of-term return voyage, offers us a dramatic description of conditions on the island of São Tomé under Company rule, and a glimpse of some of the exchanges between Portuguese settlers and WIC employees:

Less than three years earlier, the Dutch conquered the aforementioned island from the Portuguese. [...] When the Portuguese saw the Dutch taking possession of one place after another and recognised that it was now their turn, they burnt the town and retired to the castle, which they could certainly have defended themselves adequately. Nevertheless, they soon left it, returned to their country [inland], informed their king about everything and awaited orders. Meanwhile the [Dutch] commandant maintained a truce, for he had to take care, because in a few months, out of 300 men, no more than thirty remained healthy and alive. At the time of my visit, too, the people were so ill that the sentries had to sit in an armchair till officers happened to come, whereupon they stood up till they had passed. During the day they had a half-pike, but at night muskets.

As the truce with the Portuguese was still in force, some of the latter came from the castle that afternoon to trade with us, bringing us food and drink. In exchange we gave them all kinds of trade-goods, they do deal in silver money there, namely in Spanish coins. There were also goldsmiths among them, and one of these bought my tools from me. Much sugar, quite brown, grows there, and it is also milled there and exported in large quantities. This brown São Tomé sugar is well known everywhere, including here [Holland or Nuremberg]. ${ }^{49}$

49. 'Michael Hemmersam's description', p.132. 
Thus, like their American siblings, African islands were important inter-imperial commercial entrepôts and centres of cross-cultural exchanges in the Atlantic. These two important themes should be included in any future research agenda on the role of islands in the formation of the Atlantic economy during the early modern period.

\section{Author biography}

Filipa Ribeiro da Silva is Assistant Professor of History at the University of Macau. She is a member of the Global Collaboratory on the History of Labour Relations at the International Institute of Social History, Amsterdam, and Honorary Fellow of the Wilberforce Institute for the study of Slavery and Emancipation, University of Hull. Filipa was awarded BA (Honours) and MA by the New University of Lisbon in 1996 and 2002, respectively, and a PhD by Leiden University in 2009. Her monograph, Dutch and Portuguese in Western Africa: Empires, Merchants and the Atlantic System, 1580-1674, was published by Brill in 2011. 